\title{
Economic and Ecological Assessment of Transport of Various Types of Waste
}

\author{
Sylwia Guzdek', Mateusz Malinowski², Arkadiusz Religa², Daniel Liszka², \\ Agnieszka Petryk ${ }^{3}$
}

1 Department of Microeconomics, Cracow University of Economics, ul. Rakowicka 27, 31-510 Kraków, Poland, e-mail: sylwia.guzdek@uek.krakow.pl

2 Department of Bioprocesses Engineering, Energetics and Automatization, University of Agriculture in Cracow, ul. Balicka 116b, 30-149 Kraków, Poland; e-mail: mateusz.malinowski@urk.edu.pl

3 Department of Spatial Management, Cracow University of Economics, ul. Rakowicka 27, 31-510 Kraków, Poland, e-mail: agnieszka.petryk@uek.krakow.pl

*Corresponding author's e-mail: sylwia.guzdek@uek.krakow.pl

\begin{abstract}
The amount of generated waste has been increasing for several years in Poland. There is a lot of research in the field of the environmental and economic evaluation of waste treatment processes. Waste transport is considered to be one of the most important elements of waste management (WM), because it integrates the whole WM system. The environmental impact of waste transport is rising (emissions to air). The European Union introduced provisions on the principle of proximity in the Waste Framework Directive. This principle suggests that waste should generally be transported, treated or disposed of as near to its place of origin as possible. The main aim of the study was to perform an ecological and technical-economic analysis of transportation of selected types of waste (mixed municipal solid waste, construction and demolition waste, separately collected waste called: segregation). The research applied data obtained from a municipal enterprise operating in the South Poland. SimaPro 8.1 software with Ecoinvent 3.3 database was employed to calculate the environmental impact. As a result of the analysis, it was found that the transportation of $1 \mathrm{Mg}$ construction waste had twice as much negative impact on the environment as transportation of $1 \mathrm{Mg}$ mixed municipal waste and segregated waste. This is connected with higher fuel consumption per $1 \mathrm{Mg}$ of transported construction waste and twice the distance that an average hooklift truck must cover in order to collect $1 \mathrm{Mg}$ of construction waste.
\end{abstract}

Keywords: waste management (WM), municipal solid waste (MSW), wastes from construction and demolition, waste transport, life cycle assessment (LCA)

\section{INTRODUCTION}

Processes of extraction and processing of raw materials, manufacture of products and their consumption as well as the management of generated waste imply a multifaceted impact on the environment (Grzesik, 2006; Grzesik and Malinowski, 2017). This impact can be assessed by performing laboratory tests for damages that have already occurred in the ecosystem (Berg et al., 2018; Vaverková et al. 2018; Vaverková, 2019) or as a result of forecasts using computer programs
(Gentil et al., 2010). The Life Cycle Assessment (LCA) measurement technique is the result of numerous attempts to quantify the potential impact of a product or process on the environment (Kowalski et al., 2007). The LCA allows assessing the type and extent of environmental hazards generated by a product or process in successive stages of its life cycle: obtaining raw materials - production - use - disposal (PN EN ISO, 14040). This comprehensive environmental management technique covers all aspects of a product (or process) life cycle and determines its ecological 
characteristics (Chłopek and Lasocki, 2013; Szafranko, 2019). A vital link in the life cycle of a product or process includes activities related to the management of waste resulting from the consumption or use of a given object or substance: its collection, transportation, recycling and disposal (Grzesik, 2015; De Feo et al., 2016). There is many examples in literature of LCA use for WM assessment e.g. analysis the most environmentally sound plastic waste management scenario (Rigamonti et al., 2014), or the best scenarios for the household waste treatment (Panepinto et al., 2015; Grzesik and Malinowski, 2016), or the assessment of alternative strategies for biowaste recycling (Pubule et al., 2015).

Waste transport account for strategic and highly cost-intensive stage of the waste management, which determine the effectiveness of the entire logistics process of waste collection and treatment (Grzesik, 2015). Collection of waste is understood as temporary waste storage by a consumer, e.g. in a household. A shipment of waste to the treatment place is referred to as waste transport. Specially adapted means of transport are used for the waste transport (Journal of Laws of 2013, item 21). Vehicles used for waste transport show reliable ecological characteristics. Grzesik (2015) states that a commonly overlooked issue regarding waste collection and transport is unfortunately its environmental impact, as well as the contribution of this stage to the overall environmental impact caused by the waste management system. Chłopek and Lasocki (2013) reports that the quantitative assessment of possible environmental impact of a vehicle should take into account: operating conditions of internal combustion engines, pollutant emissions, greenhouse gas emissions, making an allowance for both the service life and the life of the vehicle after its decommission. This assessment can be done employing the LCA technique.

The article attempts to answer the question how the transport of various types of waste impacts the environment. The purpose of the study was to carry out an ecological analysis of transport of mixed municipal waste (garbage truck), construction waste (hooklift truck) and separately collected waste (garbage truck and hooklift truck). The research utilized data was obtained from a municipal enterprise operating in the South Poland. SimaPro 8.1 software with Ecoinvent 3.3 database was used to calculate the environmental impact. For each transported type of waste, two vehicles were analyzed in technical and economic terms.

\section{HISTORICAL OUTLINE OF THE LCA APPLICATION}

The beginnings of the Ecological Life Cycle Assessment date back to the 1960s and 1970s. Research conducted on energy consumption and the amount of waste generated in processes of production and use of products (e.g. various types of packaging) resulted in the development of a formal analytical scheme that underlies the technique in question (Kowalski et al., 2007). Energy crises in the 1980s resulted in a large number of research reports in which the LCA was also used in the context of waste management (Kowalski et al., 2007). The methodically and structurally beginnings of this measurement technique are connected with the activities of the SETAC association (The Society of Environmental Toxicology and Chemistry) founded in 1978, whose branches in Central and Eastern Europe (SETAC CEE) were established relatively late that is in 2004 (Lesiuk et al., 2015). Issued in 1993, the document called $A$ Code of Practice included the first LCA procedure, which was subject to further standardization and development by the International Organization for Standardization of a group of ISO standards, which specified the conditions and rules for applying the method (Lesiuk et al., 2015). In Poland, the use of LCA procedures is regulated by the PN-EN ISO 14040:2009 standard (Lesiuk et al., 2015).

An important assumption of the Life Cycle Assessment is the inclusion of all potential environmental impacts of a product. Not only a specific product may be subject to the LCA, but also the process of its production and use as well as the many different services associated with it. This technique provides quantitative data on the entire production process, distribution, use and reuse of the product (Szafranko, 2019). These data are the hard basis for predicting the environmental impact of the product. The conclusions drawn from the application of the LCA are therefore not merely hypothetical speculation but forecasts based on specific quantitative data. There are 3 harmful impact categories in LCA analysis of a product or process: Human health, ecosystem quality and exploitation of natural resources (Kowalski et al., 2007, Kulczycka, 2001). 
The tasks of the LCA include the identification of possible forms of the environmental impact of the product at all stages of its life cycle, the forecast of multiple interactions and the cumulative impact of negative environmental effects of the product, the indication of priority actions to improve the ecological quality of the product life cycle and a comparative analysis of various methods and measures to solve a given problem or implementation of a specific process (Lewandowska, 2006). The implementation of the tasks indicated is supported by successive, closely related stages of the research procedure carried out under the LCA: the determination of the objective and scope of analyzes, registration of stages and assessment of the impact of the product life cycle, and careful interpretation of the results obtained (Kurzydło, 2014). An integral approach to the environmental impact and generated economic effects is provided by the environmental life cycle costing (e-LCC) of the product, being equivalent to the ecological life cycle assessment (LCA), but also including life costs of the products (Joachimiak-Lechman, 2014).

The LCA technique has been subject to various applications. Its application in the assessment of pro-ecological forms of waste management in the Asti region in Italy showed that composting organic waste was more environmentally friendly than its storage (Lesiuk et al., 2015). In turn, the use of LCA to verify local waste management systems in northern Germany allowed the formulation of a typology of the most favorable waste treatment methods (Dębicka and Żygadło, 2013). Research employing the LCA in Poland confirmed the usefulness of the measurement technique for verifying the environmental impact of municipal, energy and industrial waste treatment processes (Kurzydło, 2014). Waste transport result in about $40 \%$ of the total environmental impact in the alternative fuel production system from waste in Poland (Grzesik and Malinowski, 2016; Grzesik and Malinowski, 2017). Incorporation of the LCA in mining determined the search for pro-environmental solutions limiting the consumption of energy and natural resources in mining the rock mass (Kukfisz and Maranda, 2014). The LCA was also used in the analysis of methods for assessing the technical condition of materials obtained from decommissioned cars for recycling. The research results indicated the efficiency of the three-level model of such an assessment (Chamier-Gliszczyński, 2010).

\section{ENVIRONMENTAL AND ECONOMIC SIGNIFICANCE OF WASTE TRANSPORT}

Transport conditions the development of numerous industries, agriculture and services; in addition, it links the flow of materials between supply, production and distribution departments. One of the basic elements of a well-functioning waste management system is its transport, carried out in accordance with the principles of sustainable development and the principle of proximity. The transport process is one of the reasons for degradation of natural environment; it also has a negative impact on people themselves (Badyda, 2010).

The collection and transport stage includes (Grzesik, 2015):

- collection of all household and infrastructure waste: trade, services, municipal waste from industrial facilities, together with selective collection of secondary raw materials and the removal of the waste from the place of collection,

- transport of collected waste to the processing plant: recovery, including recycling or disposal of waste, together with necessary handling or temporary storage.

Waste transportation is conducted in specialized vehicles. Numerous aspects and factors must be taken into account when selecting a means of transport for waste, but the most important one is the state of matter of the transported waste and the form of its collection at the producer. The names of the most popular means of transport used for road transportation of waste are listed below:

- solid waste: garbage trucks, dump trucks, hooklift trucks, skip loaders,

- liquid waste: cesspool emptier,

- dusty waste: silo trucks.

Road transport is one of the main sources of air pollution. It is responsible primarily for the emissions of nitrogen oxides, carbon monoxide and particulate pollutants, which affect people's health and the entire ecosystem. Grzesik (2015), as a result of the ecological assessment, concludes that the significant impact categories for the collection of mixed municipal waste transport include: photochemical ozone formation: impact on human health and plant vegetation, eutrophication: $\mathrm{N}$ potential and cumulative eutrophication potential, acidification, human toxicity, land eutrophication and climate change. High values of impact category indicators at the collection and 
transport stage are caused by substances emitted from the combustion of diesel fuel in waste collection vehicles. And so for the individual impact categories, the substances contributing to high values of the indicators include:

- for the category of photochemical ozone formation (impact on human health and plant vegetation): emissions of nitrogen oxides, NMVOC (non-methane volatile organic compounds),

- for the eutrophication category $(\mathrm{N}$ potential, land eutrophication): nitrogen oxide emissions,

- for the acidification category: emissions of nitrogen oxides, sulfur dioxide,

- for the category of toxicity to humans: emissions of nitrogen oxides, benzene, lead,

- for the category of climate change: carbon dioxide emissions.

Transport of waste to treatment plants generates certain costs. Its amount depends on the distance between the collection point and the location of the waste facilities. Undoubtedly, this has a significant impact on the selection of means of transport and the number of servicemen of vehicles. The centralization of waste facilities forces the need to build a waste trasfer station and the organization of long-distance transport, in which vehicles used on shorter routes, cannot be used due to their limited capacity (Sykut et al., 2015).

Nearly $70 \%$ of waste management costs account for expenses for collection and transport. The cost intensity of the waste transport system requires the implementation of rationalization procedures due to the rising staff costs, which is facilitated by programs for route optimization and the number of staff (Malinowski and Woźniak, 2011). The spectrum of transport costs includes four main cost categories: costs of fuel, oil and vehicle consumables consumption; costs of delivering supplies for waste collection and selection to households; technical maintenance costs as well as costs of fees, taxes and property insurance related to running a business by municipal companies (Malinowski 2016). In Kraków and the adjacent suburban communes, the highest share in the cost estimate of expenditure on transport is accounted for by the costs of fuel, remuneration for staff and provision of waste separation bags to consumers (Malinowski, 2016; Ignasiak, 2015). Waste transport in rural areas is characterized by higher costs than in urban areas (Malinowski,
2014), which mainly results from the specificity of residential development. The higher cost of transport in rural areas is also associated with lower rates of mass accumulation of waste, the terrain and road condition. These factors affect the extension of travel to households and the time of technical service, which in turn generates an increase in expenses on staff remuneration and operation of vehicles (Malinowski, 2014).

\section{MATERIALS AND METHOD}

The research was conducted on the process of transport of 3 different types of waste: mixed municipal solid waste, construction and demolition waste, waste collected separately (so-called: segregation). In order to achieve the main objective of the study:

- basic technical and economic indicators characterizing the process of transporting the aforementioned waste by vehicles selected for the analysis were determined. For each type of waste, two means of transport were designated (two garbage trucks for mixed MSW, two hooklift trucks for construction waste and a garbage truck and a hooklift truck for selectively collected waste respectively). All these vehicles were characterized by the European emission standard EURO 5. The results of the analysis are presented as average covering one year of operation of the municipal enterprise,

- a comparative analysis of the environmental impact (LCA) of waste transport was carried out in relation to $1 \mathrm{Mg}$ of transported waste of various types (mixed MSW, construction waste, segregated waste) using the TRACI 2.1 method. The analysis was carried out employing SimaPro 8.1 software and the Ecoinvent 3.3 database.

The technical and economic indicators characterizing the transport process included, inter alia:

- mass of transported waste (from the place of its generation to the place of final treatment),

- total fuel consumption (diesel fuel) in $\mathrm{dm}^{3}$,

- number of kilometers traveled $(\mathrm{km})$,

- combustion expressed in $\mathrm{dm}^{3} \cdot 100 \mathrm{~km}^{-1}$,

- fuel consumption per $1 \mathrm{Mg}$ of waste in $\mathrm{dm}^{3}$. $1 \mathrm{Mg}^{-1}$,

- average distance related to transporting $1 \mathrm{Mg}$ of waste. 
The above indicators were necessary to launch an ecological assessment of the impact of the transport process on the environment. The LCA analysis was carried out using the SimaPro 8.1 software. $1 \mathrm{Mg}$ of transported waste accounted for a functional unit. The system boundaries for LCA analysis covered the transport of waste from the place of its waste facilities together with its handling. In addition to the distance, the consumption of operating fluids and tires was also taken into account. The analysis did not include the morphological composition of the transported waste or its treatment processes.

The impact categories and categories of damage caused by a product or process are assessed in this software by estimating the burdens assigned to each impact category and categories of damage. To facilitate the interpretation of results and analyze the impact, SimaPro 8.1 recognizes the fact that the environment is a set of biological, physical and chemical parameters influencing human and natural conditions affected by, for example, a vehicle.

The main aim of the LCA is to provide a holistic insight into emissions into the environment and the consumption of natural resources caused by the waste management system or waste management installation (Bjorklund et al., 2011). The life cycle analysis is a process that requires many, very accurate data (databases), as well as methodologies that model environmental mechanisms and the effects caused by the emissions released. Therefore, the life cycle analysis is carried out using specially developed models (Grzesik, 2015). Recognized life cycle assessment methods were developed in research centers such as (Lesiuk et al., 2012): EPS 2000, CML, Eco-indicator 99, IMPACT 2002+, ReCiPe, MIPS, EDIP, TRACI etc. They have been introduced for many years in the form of models for specialized computer programs used in the LCA studies.
The TRACI 2.1 model is used to assess chemical and other environmental impacts caused by e.g. motor vehicles. This model was developed to obtain sustainability indicators, assess the impact of life cycle, industrial ecology and impact on the design process. The TRACI 2.1 enables extended quantification of factors that have potential effects in the following areas: ozone depletion, global warming, acidification, eutrophication, photochemical smog formation, carcinogens, human health disorders, ecotoxicity and what is worth mentioning in the long term fossil fuel depletion.

\section{RESULTS}

Tables 1 and 2 summarize the average characteristics of the use of vehicles transporting different groups of waste in the analyzed municipal enterprise.

Table 1 shows that the least waste was transported by the so-called small hooklift trucks that were used to transport construction and demolition waste. What is important from the point of view of this analysis is the fact that for transporting $1 \mathrm{Mg}$ of waste they had to cover a distance of as much as $45 \mathrm{~km}$ on average. The distance covered by the vehicles collecting mixed and segregated waste was similar. It is related to the fact that due to the growing segregated waste, it is very often collected and transported on the same day as mixed waste, and the vehicles travel along the same routes. The great mass of collected segregated waste resulted from the fact that bulky waste was also included in this group. The average number of kilometers traveled per $1 \mathrm{Mg}$ of mixed and segregated waste was similar and amounted to $22.3 \mathrm{~km}$ and $22.7 \mathrm{~km}$, respectively (Table 1). Table 2 lists individual vehicles, taking into account the annual fuel consumption, combustion per $100 \mathrm{~km}$ and fuel consumption for transporting $1 \mathrm{Mg}$ of waste.

Table 1. Technical characteristics of vehicles transporting waste in the analyzed company

\begin{tabular}{|c|c|c|c|c|}
\hline Type of waste transported & $\begin{array}{l}\text { Type of means of } \\
\text { transport }\end{array}$ & $\begin{array}{l}\text { Average weight of trans- } \\
\text { ported waste } \\
\left(\mathrm{Mg} \cdot \mathrm{year}^{-1}\right)\end{array}$ & $\begin{array}{l}\text { Average mile- } \\
\text { age of the ve- } \\
\text { hicles analyzed } \\
\left(\mathrm{km} \cdot \mathrm{year}^{-1}\right)\end{array}$ & $\begin{array}{c}\text { Distance per } 1 \mathrm{Mg} \text { of } \\
\text { transported waste } \\
\left(\mathrm{km} \cdot \mathrm{Mg}^{-1}\right)\end{array}$ \\
\hline Mixed municipal solid waste & Garbage trucks & 2520 & 56160 & 22.3 \\
\hline $\begin{array}{c}\text { Construction and demolition } \\
\text { waste }\end{array}$ & Hooklift trucks & 240 & 10800 & 45.0 \\
\hline $\begin{array}{l}\text { Segregated waste (glass, } \\
\text { PET, paper, metal, multi-ma- } \\
\text { terial waste, bulky waste) }\end{array}$ & $\begin{array}{l}\text { Garbage truck } \\
\text { and hooklift truck }\end{array}$ & 2376 & 54000 & 22.7 \\
\hline
\end{tabular}


Table 2. Economic characteristics of vehicles transporting waste in the analyzed company

\begin{tabular}{|c|c|c|c|c|}
\hline $\begin{array}{c}\text { Type of waste trans- } \\
\text { ported }\end{array}$ & Type of vehicle & $\begin{array}{c}\text { Average fuel consumption } \\
\left(\mathrm{dm}^{3} \cdot \mathrm{year}^{-1}\right)\end{array}$ & $\begin{array}{c}\text { Combustion per } 100 \mathrm{~km} \\
\left(\mathrm{dm}^{3} / 100 \mathrm{~km}\right)\end{array}$ & $\begin{array}{c}\text { Fuel consump- } \\
\text { tion per } 1 \mathrm{Mg} \\
\left(\mathrm{dm}^{3} / 1 \mathrm{Mg}\right)\end{array}$ \\
\hline Mixed municipal waste & Garbage trucks & 25380 & 45 & 9.3 \\
\hline $\begin{array}{c}\text { Construction and de- } \\
\text { molition waste }\end{array}$ & Hook lift trucks & 3240 & 30 & 13.5 \\
\hline $\begin{array}{c}\text { Segregated waste } \\
\text { (glass, PET, paper, } \\
\text { metal, multi-material } \\
\text { waste, bulky waste) }\end{array}$ & $\begin{array}{c}\text { Garbage truck and hook } \\
\text { lift truck }\end{array}$ & 24400 & 40 & 11.5 \\
\hline
\end{tabular}

As can be inferred from the analysis of the data compiled in Table 2, the largest fuel consumption was noted for garbage trucks transporting mixed municipal waste (over 25 thousand dm3 diesel fuel). Garbage trucks also had the highest combustion per $100 \mathrm{~km}$. The smallest combustion per $100 \mathrm{~km}$ was observed in case of hook lift trucks transporting construction waste, but at the same time these vehicles were characterized by high fuel consumption per $1 \mathrm{Mg}$ of transported waste. The data on combustion and average fuel consumption of vehicles transporting mixed municipal and segregated waste coincide with the results of Malinowski's studies $(2014,2016)$.

The results of comparison of the ecological analysis of the transport of selected types of waste are presented in Table 3. The impact of the transport of selected groups of waste on the environment is given in normalized values for 10 impact categories.

The greatest environmental impact calculated with the TRACI 2.1 model for vehicles used in the analyzed enterprise is exerted by the transport of construction waste. This is mainly due to the huge distance these vehicles have to cover in connection with the transport of $1 \mathrm{Mg}$ of construction waste. Hook lift trucks transporting construction waste have the highest impact categories for all standardized indicators. When analyzing the results obtained, particular attention should be paid to categories such as ecotoxicity, global warming, ozone depletion and carcinogenics, because the reduction of the ozone layer causes increased UVB radiation, which adversely affects the human body. Ozone depletion, and thus, increased radiation contributes to a greater number of incidences of skin cancer.

Garbage trucks transporting mixed municipal waste have the lowest environmental impact. The negative impact of the collection of mixed and segregated waste was more than twice smaller than the environmental impact of transporting construction waste. This was due to the fact that fewer kilometers were covered and less fuel was used to transport $1 \mathrm{Mg}$ of waste. The results obtained for individual impact categories, in particular for global warming and ecotoxicity in terms of mixed waste transport coincide with the results obtained by Grzesik (2015).

Table 3. Categories of environmental impact caused by the transport of different types of waste

\begin{tabular}{|c|c|c|c|c|}
\hline Impact category & Unit & $\begin{array}{c}\text { Mixed municipal solid } \\
\text { waste }\end{array}$ & $\begin{array}{c}\text { Construction and } \\
\text { demolition waste }\end{array}$ & $\begin{array}{c}\text { Segregated waste (glass, PET, } \\
\text { paper, metal, multi-material } \\
\text { waste, bulky waste) }\end{array}$ \\
\hline Ozone depletion & $\mathrm{kg} \mathrm{CFC}^{-11}$ eq & $1.15 \mathrm{E}-06$ & $2.32 \mathrm{E}-06$ & $1.17 \mathrm{E}-06$ \\
\hline Global warming & $\mathrm{kg} \mathrm{CO}_{2}$ eq & 4.9 & 9.88 & 4.99 \\
\hline Smog & $\mathrm{kg} \mathrm{O}_{2}$ eq & 0.353 & 0.712 & 0.36 \\
\hline Acidification & $\mathrm{kg} \mathrm{SO}_{2}$ eq & 0.0181 & 0.0365 & 0.0184 \\
\hline Eutrophication & $\mathrm{kg} \mathrm{N} \mathrm{eq}$ & 0.00512 & 0.0103 & 0.00523 \\
\hline Carcinogenics & $\mathrm{CTUh}$ & $1.69 \mathrm{E}-07$ & $3.41 \mathrm{E}-07$ & $1.72 \mathrm{E}-07$ \\
\hline Non carcinogenics & $\mathrm{CTUh}$ & $9.67 \mathrm{E}-07$ & $1.95 \mathrm{E}-06$ & $9.87 \mathrm{E}-07$ \\
\hline Respiratory effects & $\mathrm{kg} \mathrm{PM} \mathrm{2.5} \mathrm{eq}$ & 0.00215 & 0.00435 & 0.00219 \\
\hline Ecotoxicity & CTUe & 31.3 & 63.2 & 31.9 \\
\hline Fossil fuel depletion & MJ surplus & 10.4 & 21 & 10.6 \\
\hline
\end{tabular}




\section{CONCLUSIONS}

The use of fuel for vehicle propulsion engines results in high greenhouse gas emissions and various types of substances harmful to the environment and humans. Vehicles subjected to the ecological analysis transported mixed municipal waste, segregated waste and construction waste. The analysis reveals that

- the greatest diesel fuel combustion per $100 \mathrm{~km}$ was recorded for vehicles transporting mixed and segregated waste and the smallest one for hook lift trucks transporting construction waste,

- transport of $1 \mathrm{Mg}$ of construction and demolition waste required covering an average of as much as 45 kilometers, which was twice as high as transport of mixed and segregated waste,

- ecological transport analysis conducted applying the SimaPro 8.1 program with the TRACI 2.1 model showed that transporting construction waste had twice as much negative impact on the environment than transporting mixed municipal waste and segregated waste.

\section{Acknowledgements}

Thepublicationwaspreparedaspartofthestatutory research No. 063/WE-KMI/01/2019/S/9063.

\section{REFERENCES}

1. Act of December 14, 2012 on waste (Journal of Laws of 2013, item 21)

2. Badyda A.J. 2010. Zagrożenia środowiskowe ze strony transportu. Poznań (in Polish).

3. Berg A.B., Radziemska, M., Adamcová D., Zloch J., Vaverková M.D. 2018. Assessment strategies for municipal selective waste collection - regional waste management. Journal of Ecological Engineering, 19(1), 33-41.

4. Bjorklund A., Finnveden G., Roth L. 2011 Application of LCA in Waste Management, In: Solid Waste Technology \& Management, Christensen Th. H. (Eds.), Blackwell Publishing Ltd. 137-160.

5. Chamier-Gliszczyński N. 2010. Analiza cyklu życia obiektów technicznych w transporcie. Autobusy: technika, eksploatacja, systemy transportowe, 6, 1-8 (in Polish).

6. Chłopek Z., Lasocki J. 2013. Zastosowane metody oceny cyklu istnienia do analizy właściwości ekologicznych samochodu. Zeszyty Naukowe Instytutu
Pojazdów, 1(92), 57-66 (in Polish).

7. De Feo G., Ferrara C., Iuliano C., Grosso A. 2016. LCA of the Collection, Transportation, Treatment and Disposal of Source Separated Municipal Waste: A Southern Italy Case Study. Sustainability, 8, 1084.

8. Dębicka M., Żygadło M. 2013. The LCA as a method to support waste management system. Archives of Waste Management and Environmental Protection, 15(1), 37-46.

9. Gentil E.C., Damgaard A., Hauschild M., Finnveden G., Eriksson O., Thorneloe S., Kaplan P.O., Barlaz M., Muller O., Matsui Y., et al. 2010. Models for waste life cycle assessment: Review of technical assumptions. Waste Management, 30, 2636-2648

10. Grzesik K. 2006. Wprowadzenie do oceny cyklu życia (LCA)-nowej techniki w ochronie środowiska. Inżyniera Środowiska.11(1), 101-113 (in Polish).

11. Grzesik K. 2015. Oddziaływanie na środowisko zbiórki i transportu odpadów w systemach gospodarki odpadami komunalnymi. Logistyka, 4/2015, 8902-8910 (in Polish).

12. Grzesik K., Malinowski M. 2016. Life cycle assessment of refuse-derived fuel production from mixed municipal waste. Energy Sources, Part A: Recovery, Utilization, and Environmental Effects, 38(21), 3150-3157.

13. Grzesik K., Malinowski M. 2017. Life cycle Assessment of the mechanical - biological treatment of mixed municipal waste in Miki Recycling, Krakow, Poland. Environmental Engineering Science, 34(3), 207-220.

14. Ignasiak D., Kiciński M., Merkisz-Guranowska A. 2015. Porównanie parametrów logistycznych gospodarki odpadami komunalnymi w wybranych gminach Wielkopolski. Logistyka, 3, 1846-1857 (in Polish).

15. Joachimiak-Lechman K. 2014. Środowiskowa ocena cyklu życia (LCA) i rachunek kosztów cyklu (LCC). Aspekty porównawcze. Ekonomia i Środowisko, 1(48), 80-96 (in Polish).

16. Kowalski Z., Kulczycka J., Góralczyk M. 2007. Ekologiczna ocena cyklu życia procesów wytwórczych (LCA). PWN. Warszawa (in Polish).

17. Kukfisz B., Maranda A. 2014. Zastosowania metody oceny cyklu życia (LCA) do oszacowania wpływu na środowisko górniczych materiałów wybuchowych ładowanych mechanicznie. Chemik 68(1), 9-38 (in Polish).

18. Kulczyka J. 2001. LCA - definicje i założenia. In: Ekologiczna ocena cyklu życia (LCA) nową techniką zarządzania środowiskowego. Kulczycka J. (Eds.), PAN. Kraków (in Polish).

19. Kurzydło M. 2014. Możliwość zastosowania techniki LCA do oceny wpływu na środowisko odpadów przemysłowych i energetycznych. Inżyniera 
i Ochrona Środowiska, 17(4), 597-617 (in Polish).

20. Lesiuk A., Oleszczuk P., Kuśmierz M. 2015. Zastawanie techniki LCA w ekologicznej ocenie produktów, technologii i gospodarce odpadami (in Polish). Pozyskano z: http://www. ztch. umcs. lublin. pl/materiały/rozdział_25. pdf (access: 14.11. 2019).

21. Lewandowska A. 2006. Środowiskowa ocena cyklu życia produktu na przykładzie wybranych typów pomp przemysłowych. Wydawnictwo Akademii Ekonomicznej, Poznań. (in Polish).

22. Malinowski M., Woźniak A. 2011. Problem optymalizacji logistycznych parametrów transportu odpadów komunalnych w aspekcie strategii ekofirmy. Infrastruktura i Ekologia Terenów Wiejskich, 10, 107-119 (in Polish).

23. Malinowski M. 2014. Analiza kosztów zbierania i transportu zmieszanych odpadów komunalnych. Infrastruktura i Ekologia Terenów Wiejskich, IV/2, 1179-1191 (in Polish).

24. Malinowski M. 2016. Analiza kosztów transportu odpadów komunalnych gromadzonych selektywnie. Infrastruktura i Ekologia Terenów Wiejskich, III/2,1039-1049 (in Polish).

25. Panepinto D., Blengini G.A., Genon G. 2015. Economic and environmental comparison between two scenarios of waste management: MBT vs. thermal treatment. Resour. Conserv. Recycl., 97, 16-23.
26. PN-EN ISO 14040: 2009. Zarządzenie środowiskowe. Ocena cyklu życia. Zasady i struktura. PKN Warszawa (in Polish).

27. Pubule, J.; Blumberga, A.; Romagnoli, F.; Blumberga, D. Finding an optimal solution for biowaste management in the Baltic States. Journal of Cleaner Production, 88, 214-223.

28. Rigamonti L., Grosso M., Møller J., Martinez Sanchez V., Magnani S., Christensen T.H. 2014. Environmental evaluation of plastic waste management scenarios. Resour. Conserv. Recycl., 85, 42-53.

29. Sykut B., Kowalik K., Opielak M., Tomporowski A. 2015. Problematyka transportu odpadów komunalnych. Logistyka, 3, 4626-4631 (in Polish).

30. Szafranko E., 2019. Selected Problems of the Environmental Impact Analysis of Investment Projects Based on Life Cycle Assessment Procedure. Journal of Ecological Engineering, 20(9), 87-94.

31. Vaverková M.D., Elbl J., Radziemska M., Adamcová D., Kintl A., Baláková L., Bartoň S., Hladky J., Kynický, J., Brtnický, M. 2018. Environmental risk assessment and consequences of municipal solid waste disposal. Chemosphere, 208, 569-578.

32. Vaverková M.D., 2019. Landfill impacts on the environment - review. Geosciences (Switzerland), $9(10), 431$ 